\title{
PENGGUNAAN STRATEGI PEMBELAJARAN DAN KEMANDIRIAN BELAJAR TERHADAP HASIL BELAJAR TEKNOLOGI INFORMASI DAN KOMUNIKASI (TIK)
}

\author{
Khairil Anwar Uzir dan R. Mursid \\ SMA Negeri 2 PematangsiantarSumatera Utara dan PPs Universitas Negeri Medan \\ khairil.anwar.uzir@gmail.com
}

\begin{abstract}
Abstrak: Penelitian ini bertujuan untuk mengetahui hasil belajar TIK siswa yang diajar dengan strategi pembelajaran ARIAS dan dengan strategi pembelajaran Direct Instruction, untuk mengetahui hasil belajar TIK antara siswa dengan kemandirian tinggi dan kemandirian rendah, dan untuk mengetahui interaksi antara strategi pembelajaran dan kemandirian siswa terhadap hasil belajar TIK. Metode penelitian adalah quasi eksperimen dengan populasi penelitian adalah siswa SMA Negeri 2 Pematangsiantar. Teknik penarikan sampel dilakukan dengan cluster random sampling. Uji normalitas dengan uji Liliefors sedangkan uji homogenitas dengan uji Fisher dan uji Bartlett. Teknik analisis data adalah Anava dua jalur pada taraf signifikansi $\alpha=0,05$ yang dilanjutkan dengan uji Scheffe. Hasil penelitiannya adalah: rata-rata hasil belajar siswa yang diajar dengan strategi pembelajaran ARIAS lebih tinggi daripada rata-rata strategi pembelajaran Direct Instruction, rata-rata hasil belajar siswa dengan kemandirian tinggi lebih tinggi daripada kemandirian rendah, dan terdapat interaksi antara strategi pembelajaran dan kemandirian terhadap hasil belajar TIK.
\end{abstract}

Kata Kunci: strategi pembelajaran ARIAS dan direct instruction, kemandirian belajar, hasil belajar TIK

\begin{abstract}
This study aims to determine the ICT learning outcomes of students who are taught by ARIAS learning strategies and learning strategies Direct Instruction, to determine the ICT learning outcomes between students with high self-reliance and independence low, and to understand the interaction between learning strategies and student independence on ICT learning outcomes . The method is a quasi-experimental study with the study population are students of SMAN 2 Pematangsiantar. The sampling technique is done by cluster random sampling. Normality test with test Liliefors whereas homogeneity test with Fisher's exact test and Bartlett's test. The data analysis technique is Anava two lanes at significance level $\alpha=0.05$, followed by Scheffe test. Research results are: the average student learning outcomes are taught by instructional strategies ARIAS higher than the average of the Direct Instruction learning strategy, the average student learning outcomes with high independence higher than low self-reliance, and there was no interaction between learning strategies and self-reliance ICT on learning outcomes.
\end{abstract}

Keywords: ARIAS learning strategies and direct instruction, independent learning, ICT learning outcomes

\section{PENDAHULUAN}

Teknologi Informasi dan Komunikasi (TIK) sebagai mata pelajaran yang terhitung masih baru jika dibandingkan dengan mata pelajaran yang lain, ternyata masih dianggap sulit bagi sebagian siswa. Hal ini terjadi karena banyak siswa yang tidak memahami penyampaian materi yang dilakukan oleh guru. Selain itu, guru pun tidak terlalu banyak mendalami pemahaman siswa karena lebih fokus pada mengejar pencapaian kurikulum. Akhirnya, materi pelajaran selesai dibahas, namun kemampuan siswa terhadap materi tersebut belum memadai. Banyak siswa yang tidak bisa mengikuti alur penyampaian oleh guru karena kemampuan mereka memahami materi tersebut pun kurang.

Kemandirian belajar berperan penting dalam mempelajari TIK. Siswa harus banyak berlatih mengerjakan soal-soal latihan jika ingin paham tentang materi yang disampaikan. Telah terbukti siswa yang banyak berlatih mengerjakan soal-soal mempunyai prestasi yang lebih baik dalam pelajaran TIK dibanding dengan yang hanya belajar pada saat akan menghadapi tes atau ujian.

Penyebab lain dari keterpurukan pembelajaran TIK adalah masih banyak guru 
yang menggunakan variasi dalam mengajar yang mengakibatkan siswa pasif selama proses pembalajaran. Hal itu dikarenakan dalam stategi mengajar ini tugas siswa adalah mendengar serta mencatat hal-hal pokok dari yang dikemukakan oleh guru sehingga segala potensi yang ada dalam diri siswa kurang begitu optimal dalam pemberdayaannya.

Berdasarkan pengamatan penulis penyebab rendahnya hasil belajar TIK diduga disebabkan oleh beberapa faktor diantaranya: (1) masih rendahnya ketersediaan fasilitas komputer, dimana perangkat komputer yang tersedia belum mencukupi untuk satu orang siswa menggunakan satu perangkat komputer dalam prakteknya, sehingga harus dilakukan dengan membagi siswa kedalam 2 kelompok untuk setiap kelasnya. (2) jumlah rombongan belajar tiap tingkatan terdiri dari 8 rombangan belajar sedangkan laboratorium komputer hanya satu ruangan sehingga menyebabkan praktek dilakukan secara bergiliran sehingga setiap kelasnya hanya mendapatkan jam praktek hanya satu bulan sekali. (3) guru-guru TIK di lingkungan SMA Negeri 2 Kota Pematangsiantar masih menggunakan strategi pembelajaran konvensional, dimana guru masih mendominasi proses belajar mengajar atau teacher centered dan siswa tidak diaktifkan dalam suasana pembelajaran yang dapat meningkatkan kemandirian siswa dalam belajar.

Tuntutan kemandirian belajar akan semakin kuat dengan menggunakan strategi pembelajaran yang bermakna serta pemanfaatan teknologi pada pelajaran TIK yang dapat dipergunakan untuk membantu siswa belajar sehingga mereka dapat belajar lebih mudah, lebih cepat, lebih pasti dan/atau lebih murah. Kemandirian belajar diperlukan oleh siswa yang menghadapi tugas, kajian mandiri, tugas dalam bentuk proyek yang terbuka atau pemecahan masalah, penyusunan makalah. Ketika siswa menghadapi tugas-tugas tersebut maka siswa dihadapkan pada sumber informasi yang relevan ataupun tidak relevan dengan kebutuhan dan tujuan siswa. Pada kondisi tersebut siswa harus memiliki inisiatif sendiri dan kemandirian menganalisis kebutuhan atau merumuskan tujuan, memilih dan menerapkan strategi penyelesaian masalah, memilih sumber yang relevan serta mengevaluasi diri terhadap pembelajarannya.

Hasil belajar TIK berupa kemampuan yang dimiliki siswa yaitu berupa pengetahuan dan keterampilan yang diperoleh siswa setelah selesai proses pembelajaran yang dapat dilihat dari perubahan tingkah laku siswa, misalnya seorang siswa mampu dan trampil menjelaskan dan mengidentifikasikan menu dan icon pengolahan kata dan membuat langkah-langkah pembuatan dokumen pengolahan kata dengan variasi tabel, grafik, gambar dan diagram pada aplikasi microsof word.

Hasil belajar TIK adalah kemampuan yang diperoleh siswa setelah mengikuti serangkaian kegiatan belajar yang tercermin pada cara memanfaatkan perangkat komputer sebagai alat bantu dalam menyelesaikan permasalah yang harus diselesaikan dalam kehidupan sehari-hari. Cara mengukur hasil belajar yang selama ini digunakan adalah dengan mengukur tes-tes, yang biasa disebut dengan ulangan. Tes dibagi menjadi dua yaitu: tes formatif dan tes sumatif. Tes formatif adalah tes yang diadakan sebelum atau selama pelajaran berlangsung, sedangkan tes sumatif adalah tes yang diselenggarakan pada saat keseluruhan kegiatan belajar mengajar, tes sumatif merupakan ujian akhir semester.

Dick \& Carey (1996) menjelaskan strategi pembelajaran adalah prosedur atau tahapan kegiatan belajar yang digunakan dalam rangka membantu peserta didik mencapai tujuan pembelajaran tertentu. Prosedur atau tahapan kegiatan belajar itu mungkin dilakukan pengajar, mungkin juga dilakukan siswa sendiri dengan menggunakan buku, gambar, program televisi atau kombinasi berbagai media, baik oleh pengajar maupun oleh siswa sendiri, kegiatan itu haruslah terencana secara sistematik untuk dapat disebut kegiatan pembelajaran.

Strategi pembelajaran ARIAS dikembangkan oleh Keller \& Thomas (1987) yang merupakan modifikasi dari strategi ARCS (attention, relevance, confidence, statisfaction) merupakan jawaban pertanyaan "bagaimana" merancang pembelajaran yang dapat mempengaruhi motivasi berprestasi dan hasil belajar siswa. Namun pada Strategi pembelajaran ini tidak ada evaluasi (assessment), padahal evaluasi merupakan komponen yang tidak dapat dipisahkan dalam kegiatan pembelajaran. Evaluasi yang dilaksanakan selama proses pembelajaran menurut Sauders et al. Yang dikutip Berard dan Senior (1980) dapat mempengaruhi hasil belajar siswa. Mengingat pentingnya evaluasi, maka strategi pembelajaran ini dimodifikasi dengan menambahkan komponen evaluasi pada strategi pembelajaran tersebut. 
Arends (1997) menyatakan "The term teaching Strategi refes to a particular approach to instrction that includes its goals, syntax, environment, and management system,". Istilah Strategi pengajaran mengarah pada suatu pendekatan pembelajaran tertentu termasuk tujuannya, sintaksnya, lingkungannya dan sistem pengelolaannya. Lebih lanjut dalam buku lain Arends menyampaikan bahwa tidak ada satupun Strategi pembelajaran yang lebih baik dibandingkan Strategi pembelajaran lainnya, namun beliau menekankan bahwa Strategi yang tepat sangat tergantung pada karakteristik siswa, materi ataupun tujuan yang ingin dicapai oleh guru. Strategi pembelajaran tersebut bisa berbentuk theaching Strategis pendekatan yang berpusat pada guru ataupun students Strategis pendekatan yang berpusat pada siswa, lebih lanjut dijelaskan bahwa penggunaan Strategi tertentu membantu guru mencapai sebagaian tujuan, tetapi bukan untuk tujuan yang lain. (Arends : 2008).

Brady (1985) mengemukakan bahwa Strategi pembelajaran dapat diartikan sebagai blueprint yang dapat dipergunakan untuk membantu guru dalam mempersiapkan dan melaksanakan pembelajaran. Untuk lebih memahami strategi pembelajaran selanjutnya ia mengemukakan 4 premis tentang strategi pembelajaran yaitu: (1) Strategi memberikan arah untuk persiapan dan implementasi kegiatan pembelajaran. Karena itu strategi pembelajaran lebih bermuatan praktis implementatif daripada bermuatan teori. (2) meskipun terdapat sejumlah strategi pembelajaran yang berbeda, namun pemisahan antara satu strategi dengan strategi yang lain tidak bersifat deskrit, namun memiliki keterkaitan. (3) tidak ada satupun strategi pembelajaran yang memiliki kedudukan lebih penting dan lebih baik dari yang lain. Tidak satupun strategi tunggal yang dapat merealisasikan berbagai jenis dan tingkatan tujuan pembelajaran yang berbeda. (4) pengetahuan guru tentang strategi pembelajaran memiliki arti penting dalam mewujudkan efisiensi dan efektifitas pembelajaran.

Kemandirian belajar atau SelfRegulated Learning diperlukan agar siswa mereka mempunyai tanggung jawab dalam mengatur dan mendisiplinkan dirinya, selain itu dalam mengembangkan kemampuan belajar atas kemauan sendiri. Sikap-sikap tersebut perlu dimiliki oleh siswa sebagai peserta didik karena hal tersebut merupakan ciri dari kedewasaan orang terpelajar. Kemandirian adalah hal atau keadaan dapat berdiri sendiri tanpa bergantung pada orang lain (KBBI : 1991). Prasasti (2004) mengemukakan bahwa kemandirian adalah kemampuan untuk melakukan kegiatan atau tugas sehari-hari atau dengan sedikit bimbingan sesuai dengan tahapan perkembangan dan kapasitasnya.

Marun dkk (1986) menyatakan ada beberapa istilah yang digunakan untuk menyatakan kemandirian yaitu autonomy, independency dan self reliance. Teori kebutuhan psikologis dari Murray sebagaimana dikutip oleh Hall dan Lindzey (1970) mengemukakan bahwa perilaku manusia digerakkan oleh sejumlah kebutuhan psikologis, antara lain need for autonomy dan need for defence. Need for autonomy berarti kebutuhan mendapatkan kebebasan, melepaskan diri dari tekanan, dan keluar dari lingkungan, meninggalkan aktivitas-aktivitas yang ditentukan oleh dominasi kekuasaan secara mandiri dan bebas berbuat sesuai dengan kata hati, tidak terikat dan menentang kebiasaan. Sedangkan Need for defence cenderung menghormati dan mendukung suatu kekuatan tertentu, menerima pengaruh kelompok lain dan menyesuaikan diri dengan kebiasaan.

Sukardi (1993) menyatakan bahwa kebutuhan untuk mandiri memiliki ciri-ciri sebagai berikut: (1) berbuat sebagaimana yang diinginkannya, (2) mengatakan apa yang sedang dipikirkannya, (3) tidak tergantung kepada orang lain dalam mengambil keputusan, (4) merasa bebas untuk melakukan apa yang ingin dilakukannya, (5) melakukan sesuatu yang ada di luar peraturan atau kebiasaan, (6) menghindari situasi dimana seseorang diharapkan bisa untuk menyesuaikan diri, (7) melakukan sesuatu tanpa menghormati gagasan orang lain dan (8) mengkritik ornag-orang yang berkuasa.

Ausubel sebagaimana dikutip Masrun dkk (1986) menyatakan independency dapat dibedakan atau dua golongan, yaitu volitional independency dan executive independency. Perilaku mandiri tercermin dalam perilaku yang sesuai dengan kehendak sendiri dalam menyatakan buah pikiran sendiri, bebas dalam mengambil keputusan, merasa mempunyai kebebasan utuk mengerjakan segala sesuatu sesuai dengan kebutuhannya, menghindari situasi dimana ia diharapkan menyesuaikan diri dan mengerjakan sesuatu tanpa memperdulikan apa yang dipikirkan orang lain. Sebaliknya perilaku yang tidak mandiri tercermin dalam mendapatkan saran dari orang lain, mengikuti petunjuk dan mengerjakan seperti yang 
diharapkan, menerima kepemimpinan orang lain, menyesuaikan diri dengan kebiasaan dan menghindari perubahan-perubahan kebiasaan serta membiarkan orang lain membuat keputusan.

Sesuai dengan rumusan masalah di atas, tujuan yang ingin dicapai dalam penelitian ini adalah untuk mengetahui: (1) Hasil belajar TIK siswa yang diajarkan dengan strategi pembelajaran ARIAS lebih tinggi dari pada strategi Direct Instruction; (2) Siswa yang memiliki kemandirian belajar yang berbeda akan memperoleh hasil belajar yang berbeda pula; (3) Interaksi antara strategi pembelajaran dan kemandirian belajar dalam mempengaruhi hasil belajar TIK.

Berdasarkan uraian pada kajian teori dan kerangka berpikir di atas, maka dapat diajukan hipotesis dalam penelitian ini yaitu sebagai berikut: (1) Hasil belajar TIK siswa yang diajar dengan strategi pembelajaran ARIAS lebih tinggi daripada hasil belajar TIK siswa yang diajar dengan strategi pembelajaran Direct Instruction. (2) Hasil belajar TIK siswa dengan tingkat kemandirian tinggi lebih tinggi dari pada hasil belajar TIK siswa dengan kemandirian rendah; dan (3) Terdapat interaksi antara Strategi pembelajaran dan kemandirian terhadap hasil belajar siswa.

\section{METODE PENELITIAN}

Penelitian dilaksanakan pada siswa kelas X semester genap tahun ajaran 2011/2012 di SMA Negeri 2 Pematangsiantar. Populasi penelitian adalah seluruh siswa SMA Negeri 2 Pematangsiantar kelas $\mathrm{X}$ tahun ajaran 2011/2012 sebanyak 313 siswa yang terdiri dari 9 kelas. Teknik pengambilan sampel dalam penelitian ini adalah teknik acak kelompok (cluster random sampling) yakni dari 9 kelas dipilih 2 kelas sebagai sampel penelitan. Selanjutnya melalui pengacakan maka kelas X7 terpilih sebagai kelas yang akan diberi perlakukan dengan strategi pembelajaran ARIAS, sedangkan kelas X-8 terpilih sebagai kelas yang diberi perlakuan strategi pembelajaran Direct Instruction.Penelitian ini adalah penelitian kuantitatif dengan jenis penelitian kuasi eksperimen desain faktorial 2x2. Melalui desain ini akan dibandingkan pengaruh strategi pembelajaran ARIAS dengan strategi pembelajaran Direct Instruction, terhadap hasil belajar TIK siswa ditinjau dari siswa yang memiliki kemandirian tinggi dan rendah. Strategi pembelajaran ARIAS dan Direct Instruction diperlakukan kepada kelompok eksperimen siswa, baik dengan tingkat kemandirian tinggi maupun rendah. Strategi pembelajaran ARIAS dan strategi pembelajaran Direct Instruction adalah sebagai variabel bebas, tingkat kemandirian tinggi dan rendah sebagai variabel moderator, serta hasil belajar TIK sebagai variabel terikat.

Teknik analisa data yang digunakan untuk pengujian hipotesis adalah teknik statistik deskriptif dan inferensial. Teknik statistik deskriptif digunakan untuk mendeskripsikan data, antara lain : nilai rata-rata(mean), median, modus, varians dan simpangan baku. Teknik statistik inferensial digunakan untuk menguji hipotesis penelitian, dimana teknik inferensial yang akan digunakan adalah teknik Analisis Varians dua jalur (disain faktorial $2 \times 2$ ) dengan taraf signifikan 0,05.

Sebelum pengujian hipotesis dilaksanakan, terlebih dahulu dilakukan uji persyaratan analisis dan sebelum dilakukan pengujian-pengujian, data terlebih dahulu dideskripsikan. Dalam deskripsi data dilaporkan tentang mean, standar deviasi, modus, median, nilai maksimum dan nilai minimum.

Untuk uji persyaratan analisis dilakukan pengujian normalitas untuksemua variabel dengan menggunakan uji Liliefors. Kriteria yang digunakan adalah data berdistribusi normal jika $\mathrm{L}_{\text {hitung }}<\mathrm{L}_{\text {tabel }}$ pada taraf signifikansi 5\%. Selain uji normalitas dilakukan juga uji homogenitas variabel dilakukan dengan uji Fisher (uji F) dengan taraf signifikansi 5\%. Homogen atau tidaknya ditentukan oleh besarnya nilai Fisher dengan kriteria bahwa data memiliki varians homogen jika perbandingan antara nilai probabilitas hitung menunjukkan nilai lebih kecil dari nilai tabel pada taraf signifikani 5\%.

Setelah pengujian persyaratan analisis maka dilanjutkan pengujian hipotesis dengan teknik analisis varians untuk tiap variabel beserta interaksinya. Untuk pengujian hipotesis dilakukan pada taraf signifikansi 5\%. Selanjutnya dilakukan uji lanjut dengan menggunakan Uji Scheffee' karena jumlah responden setiap kelompok berbeda.

\section{HASIL DAN PEMBAHASAN Hasil}

Pengujian hipotesis dilakukan menggunakan teknik analisis varians (ANAVA) faktorial $2 \times 2$. Untuk keperluan analisis varians, data yang diperlukan dapat dilihat pada tabel berikut ini : 
Tabel 1. Rangkuman Data Hasil Belajar TIK

\begin{tabular}{|c|c|c|c|}
\hline Kemandirian & ARIAS & $\begin{array}{c}\text { Direct } \\
\text { Instruction }\end{array}$ & Total \\
\hline Tinggi & $\begin{aligned} \mathrm{n} & =14 \\
\sum \mathrm{X} & =456 \\
\sum \mathrm{X}^{2} & =14930 \\
\bar{X} & =32,93 \\
\mathrm{~s} & =2,50\end{aligned}$ & $\begin{aligned} \mathrm{n} & =15 \\
\Sigma \mathrm{X} & =418 \\
\Sigma \mathrm{X}^{2} & =11812 \\
\bar{X} & =28,20 \\
\mathrm{~s} & =3,67\end{aligned}$ & $\begin{aligned} \mathrm{n} & =29 \\
\sum \mathrm{X} & =874 \\
\sum \mathrm{X}^{2} & =26742 \\
\bar{X} & =30,22 \\
\mathrm{~s} & =2,90\end{aligned}$ \\
\hline Rendah & $\begin{aligned} \mathrm{n} & =22 \\
\Sigma \mathrm{X} & =564 \\
\Sigma \mathrm{X}^{2} & =14638 \\
\bar{X} & =25,86 \\
\mathrm{~s} & =3,14\end{aligned}$ & $\begin{aligned} \mathrm{n} & =21 \\
\Sigma \mathrm{X} & =529 \\
\Sigma \mathrm{X}^{2} & =13809 \\
\bar{X} & =26,14 \\
\mathrm{~s} & =4,03\end{aligned}$ & $\begin{aligned} \mathrm{n} & =43 \\
\sum \mathrm{X} & =1093 \\
\Sigma \mathrm{X}^{2} & =28447 \\
\bar{X} & =25,415 \\
\mathrm{~s} \quad & =3,42\end{aligned}$ \\
\hline Total & $\begin{aligned} \mathrm{n} & =36 \\
\Sigma \mathrm{X} & =1020 \\
\Sigma \mathrm{X}^{2} & =29568 \\
\bar{X} & =29,11 \\
\mathrm{~s} & =2,66\end{aligned}$ & $\begin{aligned} \mathrm{n} & =36 \\
\Sigma \mathrm{X} & =947 \\
\Sigma \mathrm{x}^{2} & =25621 \\
\bar{X} & =26,53 \\
\mathrm{~s} & =3,67\end{aligned}$ & $\begin{aligned} \mathrm{n} & =72 \\
\sum \mathrm{X} & =1967 \\
\sum \mathrm{X}^{2} & =55189 \\
\bar{X} & =27,82 \\
\mathrm{~s} & =3,16\end{aligned}$ \\
\hline
\end{tabular}

Rangkuman hasil perhitungan analisis varians untuk menguji hipotesisnya dapat dilihat pada Tabel 2 berikut ini :

Tabel 2. Rangkuman Anava Faktorial 2 x 2

\begin{tabular}{|c|c|c|c|c|c|}
\hline Sumber Variasi & $\mathrm{dk}$ & $\mathrm{Jk}$ & $\mathrm{Rjk}$ & Fhitung & $\begin{array}{c}F_{\text {tabel }}(1,68) \\
(\alpha=0,05)\end{array}$ \\
\hline Strategi Pembelajaran & 1 & 385,74 & 385,74 & 29,03 & \multirow{5}{*}{3,98} \\
\hline Kemandirian & 1 & 74,01 & 74,01 & 5,57 & \\
\hline Interaksi & 1 & 88,41 & 88,41 & 6,65 & \\
\hline Galat & 68 & 903,49 & 13,29 & & \\
\hline Total & 71 & 1451,65 & - & & \\
\hline
\end{tabular}

Berdasarkan rangkuman di atas maka akan dirinci pengujian hipotesis sebagai berikut

Pengujian hipotesis pertama yaitu hasil belajar TIK siswa yang diajarkan dengan strategi pembelajaran ARIAS lebih tinggi daripada hasil belajar TIK siswa yang diajar dengan strategi pembelajaran Direct Instruction. Hipotesis statistiknya adalah :

$\mathrm{H} 0: \mu \mathrm{A} 1=\mu \mathrm{A} 2$
$\mathrm{Ha}: \mu \mathrm{A} 1>\mu \mathrm{A} 2$

Berdasarkan perhitungan anava faktorial 2 × 2 diperoleh Fhitung $=29,03$ sedang nilai Ftabel $=3,98$ untuk dk $(1,68)$ dan taraf nyata $\alpha=0,05$. Ternyata nilai Fhitung $=$ $29,03>$ Ftabel $=3,98$, sehingga pengujian hipotesis menolak Ho. Dengan demikian dapat ditarik kesimpulan bahwa hasil belajar TIK siswa yang diajar dengan strategi pembelajaran ARIAS lebih baik dibandingkan dengan hasil 
belajar TIK siswa yang diajar dengan strategi pembelajaran Direct Instruction teruji kebenarannya. Hal ini juga terlihat dari rata-rata hasil belajar TIK siswa yang diajar dengan strategi pembelajaran ARIAS $(X=27,61)$ lebih tinggi dari hasil belajar TIK siswa yang diajar dengan strategi pembelajaran Direct Instruction $(X=26,42)$.

Pengujian hipotesis kedua yaitu hasil belajar TIK siswa dengan kemandirian tinggi lebih tinggi dari pada hasil belajar TIK siswa dengan kemandirian rendah. Hipotesis statistiknya adalah sebagai berikut :

$\mathrm{H} 0: \mu \mathrm{B} 1=\mu \mathrm{B} 2$

$\mathrm{Ha}: \mu \mathrm{B} 1>\mu \mathrm{B} 2$

Berdasarkan perhitungan anava faktorial 2 x 2 diperoleh Fhitung $=5,57$ sedangkan nilai Ftabel $=3,98$ untuk dk $(1,68)$ dan taraf nyata $\alpha=0,05$. Ternyata nilai Fhitung $=5,57>$ Ftabel $=3,98$ sehingga hipotesis menolak H0. Dengan demikian dapat ditarik kesimpulan bahwa hasil belajar TIK siswa dengan kemandirian tinggi lebih tinggi dari pada hasil belajar TIK siswa dengan kemandirian rendah teruji kebenarannya. Hal ini juga terlihat dari rata-rata hasil belajar TIK siswa dengan kemandirian tinggi $(X=30,22)$ lebih tinggi dari hasil belajar TIK siswa dengan kemandirian rendah $(X=25,41)$.

Pengujian hipotesis ketiga yaitu terdapat interaksi antara strategi pembelajaran dan kemandirian dalam memberikan pengaruh terhadap hasil belajar TIK siswa. Hipotesis statistiknya adalah :

$\mathrm{H} 0: \mathrm{A}><\mathrm{B}=0$

$\mathrm{Ha}: \mathrm{A}><\mathrm{B} \neq 0$

Berdasarkan perhitungan anava faktorial $2 \times 2$ diperoleh Fhitung $=6,65$ sedang nilai Ftabel $=3,98$ untuk dk $(1,68)$ dan taraf nyata $\alpha=0,05$. Ternyata nilai Fhitung $=6,65>$ dari Ftabel $=3,98$ sehingga pengujian hipotesis menolak H0. Dengan demikian dapat ditarik kesimpulan bahwa terdapat interaksi antara strategi pembelajaran dan kemandirian dalam memberikan pengaruh terhadap hasil belajar TIK siswa teruji kebenarannya.

Selanjutnya dilakukan uji lanjut dengan uji Scheffe. Perhitungan untuk uji Scheffe, dapat dilihat pada lampiran 10. Rangkuman perhitungan uji Scheffe' tertera pada Tabel 3. berikut :

Tabel 3. Rangkuman Hasil Uji Scheffe'

\begin{tabular}{|c|c|c|c|}
\hline \multicolumn{2}{|c|}{ Hipotesis Statistik } & Fhitung & $\begin{array}{c}F_{\text {tabel }(3,68)} \\
(\alpha=0,05)\end{array}$ \\
\hline $\mathrm{H}_{0}: \mu_{11}=\mu_{12}$ & $\mathrm{Ha}: \mu_{11}>\mu_{12}$ & 2,74 & 2,71 \\
\hline $\mathrm{H}_{0}: \mu_{11}=\mu_{21}$ & $\mathrm{Ha}: \mu_{11}>\mu_{21}$ & 4,55 & 2,71 \\
\hline $\mathrm{H}_{0}: \mu_{11}=\mu_{22}$ & $\mathrm{Ha}: \mu_{11}>\mu_{22}$ & 4,29 & 2,71 \\
\hline $\mathrm{H}_{0}: \mu_{12}=\mu_{21}$ & $\mathrm{Ha}: \mu_{12}>\mu_{21}$ & 1,57 & 2,71 \\
\hline $\mathrm{H}_{0}: \mu_{12}=\mu_{22}$ & $\mathrm{Ha}: \mu_{12}>\mu_{22}$ & 1,36 & 2,71 \\
\hline $\mathrm{H}_{0}: \mu_{21}=\mu_{22}$ & $\mathrm{Ha}: \mu_{21}>\mu_{22}$ & 0,28 & 2,71 \\
\hline
\end{tabular}

Keterangan :

$\mu 11$ = Rata-rata hasil belajar kelompok siswa yang diajar dengan strategi pembelajaran ARIAS dan kemandirian tinggi

$\mu 12=$ Rata - rata hasil belajar kelompok siswa yang diajar dengan strategi pembelajaran Direct Instruction dan kemandirian tinggi

$\mu 21=$ Rata-rata hasil belajar kelompok siswa yang diajar dengan strategi pembelajaran ARIAS dan kemandirian rendah

$\mu 22=$ Rata-rata hasil belajar kelompok siswa yang diajar dengan strategi pembelajaran Direct Instruction dan kemandirian rendah

Secara umum keseluruhan hasil uji Scheffe menunjukkan dari enam kombinasi perbandingan rata-rata hasil belajar TIK maka berdasarkan Tabel 3 terdapat tiga dari enam menunjukkan hasil yang tidak signifikan. Tiga yang tidak signifikan tersebut adalah : (1) ratarata hasil belajar TIK kelompok siswa yang diajar dengan strategi pembelajaran Direct Instruction dan kemandirian tinggi dengan ratarata hasil belajar kelompok siswa yang diajar dengan strategi pembelajaran ARIAS dan kemandirian rendah, (2) rata-rata hasil belajar 
TIK kelompok siswa yang diajar dengan strategi pembelajaran Direct Instruction dan kemandirian tinggi dengan rata-rata hasil belajar kelompok siswa yang diajar dengan strategi pembelajaran Direct Instruction dan kemandirian rendah, dan (3) rata-rata hasil belajar TIK kelompok siswa yang diajar dengan strategi pembelajaran ARIAS dan kemandirian rendah dengan rata-rata hasil belajar kelompok siswa yang diajar dengan strategi pembelajaran Direct Instruction dan kemandirian rendah.

Namun demikian terdapat interaksi strategi pembelajaran dan kemandirian terhadap hasil belajar TIK, hal ini terlihat dari : (1) strategi pembelajaran ARIAS memberikan hasil belajar TIK yang lebih tinggi pada siswa dengan kemandirian tinggi daripada siswa dengan kemandirian rendah, dan (2) strategi pembelajaran Direct Instruction memberikan hasil belajar TIK yang lebih tinggi pada siswa dengan kemandirian tinggi daripada siswa dengan kemandirian rendah, juga terbukti. Hal ini diketahui dari rata-rata skor siswa yang diajar dengan strategi pembelajaran ARIAS pada siswa dengan kemandirian tinggi ( $X=$ 32,93) lebih tinggi dari siswa dengan kemandirian rendah $(X=25,86)$ dan rata-rata skor siswa yang diajar dengan strategi pembelajaran Direct Instruction pada siswa dengan kemandirian tinggi ( $X=28,20$ ) lebih tinggi dari siswa dengan kemandirian rendah ( $X=26.14)$.

Interaksi strategi pembelajaran dan kemandirian dapat ditunjukkan pada gambar berikut ini :

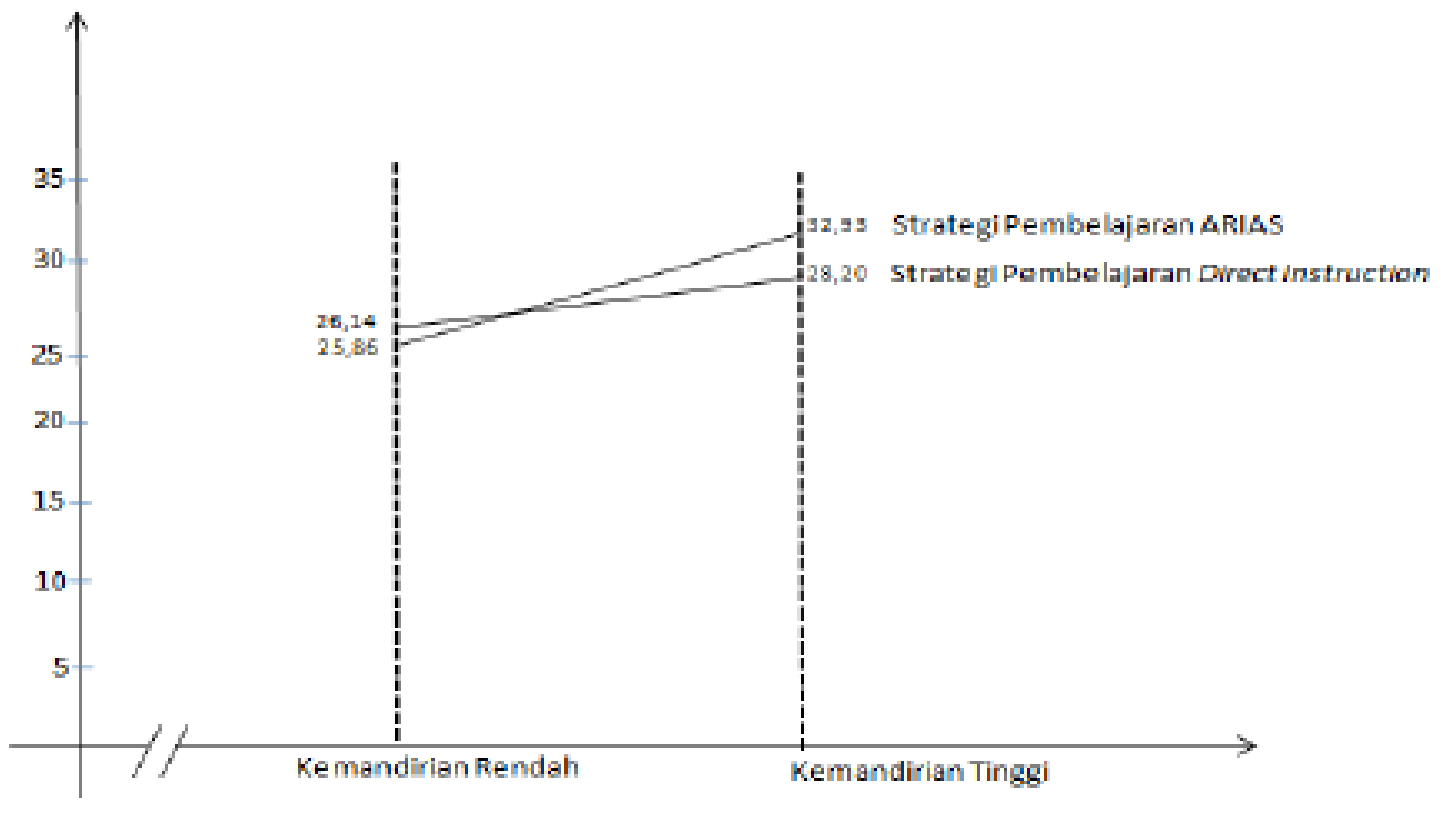

Gambar 1. Interaksi Antara Strategi Pembelajaran dan Kemandirian

\section{Pembahasan}

Dari perhitungan statistik di atas, maka terlihat secara keseluruhan ratarata hasil belajar TIK siswa yang diajarkan dengan strategi pembelajaran ARIAS ( $X=29,11)$ lebih tinggi daripada rata-rata hasil belajar TIK siswa yang diajar dengan pembelajaran Direct Instruction $(X=26,53)$. Hal ini menunjukkan bahwa strategi pembelajaran ARIAS terbukti lebih efektif dapat meningkatkan hasil belajar TIK siswa secara keseluruhan baik untuk kelompok siswa dengan kemandirian tinggi maupun kemandirian rendah. Dari hasil temuan ini menunjukkan bahwa untuk mengajarkan materi TIK lebih efektif menggunakan strategi pembelajaran ARIAS daripada strategi pembelajaran Direct Instruction.

Jika diperhatikan lebih lanjut bahwa dalam strategi pembelajaran ARIAS rata-rata hasil belajar TIK siswa dengan kemandirian tinggi $(X=32,93)$ lebih baik daripada hasil belajar TIK siswa dengan kemandirian rendah $(X=25,86)$. Sedangkan pada strategi pembelajaran Directd Instruction, rata-rata hasil belajar TIK siswa dengan kemandirian tinggi $(X$ $=28,20)$ lebih baik daripada hasil belajar TIK dengan kemandirian rendah $(X=26,14)$. Hal ini menunjukkan bahwa kemandirian cukup signifikan untuk membedakan hasil belajar siswa, dimana hasil belajar siswa dengan kemandirian tinggi baik yang diajar dengan 
strategi pembelajaran ARIAS maupun strategi pembelajaran Direct Instruction lebih baik daripada hasil belajar siswa dengan kemandirian rendah.

Hasil penelitian ternyata menunjukkan semua hipotesis penelitian yaitu: (1) hasil belajar TIK siswa yang diajar dengan strategi pembelajaran ARIAS lebih tinggi daripada hasil belajar siswa yang diajar dengan strategi pembelajaran Direct Instruction. (2) hasil belajar TIK siswa dengan kemandirian tinggi lebih tinggi daripada hasil belajar TIK siswa dengan kemandirian rendah, dan (3) terdapat interaksi antara strategi pembelajaran dan kemandirian memberikan pengaruh terhadap hasil belajar siswa, dapat diterima ketigatiganya.

Hipotesis pertama yang menyatakan hasil belajar TIK antara siswa yang diajar dengan strategi pembelajaran ARIAS lebih tinggi daripada hasil belajar TIK siswa yang diajar dengan strategi pembelajaran Direct Instruction. Hal ini dapat dimaklumi karena melalui strategi pembelajaran ARIAS dapat mendorong siswa untuk aktif belajar karena siswa dapat menghubungkan yang mereka pelajari dengan kehidupan sehari-hari, siswa lebih memahami materi ajar karena sumbersumber belajar yang beraneka ragam. Disamping itu strategi pembelajaran ARIAS bertujuan untuk menumbuhkan sikap percaya, yakin akan berhasil atau yang berhubungan dengan harapan untuk berhasil, berhubungan dengan kehidupan siswa baik berupa pengalaman sekarang atau yang telah dimiliki maupun yang berhubungan dengan kebutuhan karir sekarang atau yang akan datang, berhubungan dengan minat/perhatian siswa, berhubungan dengan penilaian terhadap siswa, dan dapat memberikan rasa bangga dan puas pada siswa. Sebagaimana yang dikemukan oleh Sopah (2007) bahwa pembelajaran ARIAS didasari atas teori belajar Gagne yaitu belajar adalah suatu proses untuk memperoleh motivasi dalam pengetahuan, keterampilan, kebiasaan dan tingkah laku dan teori belajar Ausubel yaitu belajar yang bermakna dimana variabel dalam belajar bermakna ini mencakup perangkat fakta-fakta, konsep-konsep, generalisasigeneralisasi yang terorganisasi, yang telah dipelajari dan dikuasi seseorang.

Temuan penelitian ini sejalan dengan hasil penelitian Megalia (2010) yang berjudul "Pembelajaran Matematika Dengan Menggunakan Strategi ARIAS Dalam Upaya Meningkatkan Kemampuan Berpikir Kreatif
Siswa SMA: Penelitian Eksperimen Terhadap Siswa Kelas XI IPA SMA Negeri 1 Lembang" hasil kesimpulan penelitan menunjukkan bahwa peningkatan kemampuan berpikir siswa yang mengunakan strategi ARIAS lebih baik dari siswa yang menggunakan strategi pembelajaran konvensional.

Pengujian hipotesis kedua mununjukkan bahwa hasil belajar TIK dari siswa dengan kemandirian tinggi lebih tinggi dari pada hasil belajar TIK siswa dengan kemandirian rendah. Hasil ini membuktikan bahwa kemandirian signifikan untuk membedakan hasil belajar TIK. Kemandirian dalam penelitian ini dikategorikan atas kemandirian tinggi dan kemandirian rendah. Hasil analisis data secara keseluruhan diperoleh rata-rata hasil belajar TIK siswa dengan kemandirian tinggi lebih baik daripada hasil belajar TIK siswa dengan kemandirian rendah. Hal ini berindikasi bahwa siswa dengan kemandirian tinggi secara rata-rata mempunya hasil belajar TIK yang lebih baik dibandikan dengan siswa dengan kemandirian rendah. Dengan demikian siswa dengan kemandirian tinggi lebih memahami dan menguasai materi pelajaran TIK dibandingkan dengan siswa kemandirian rendah.

Temuan penelitian ini mendukung penelitian yang dilakukan oleh Hidayat (2009) tentang Peningkatan Kemampuan Komunikasi Matematika dan Kemandirian Belajar Siswa Sekolah Menengah Pertama Dengan Menggunakan Pendekatan Matematika Realitik, menemukan bahwa hasil belajar siswa dengan tingkat kemandirian tinggi lebih unggul daripada hasil belajar siswa dengan tingkat kemandirian rendah.

Dari pengujian hipotesis ketiga terdapat interaksi antara strategi pembelajaran dan kemandirian dalam mempengaruhi hasil belajar TIK siswa. Apabila dilihat dari rata-rata hasil belajar TIK pada kelompok siswa dengan kemandirian tinggi diajar dengan strategi pembelajaran ARIAS lebih tinggi dibandingkan dengan rata-rata hasil belajar TIK kelompok siswa dengan kemandirian rendah dan diajar dengan strategi pembelajaran Direct Instruction. Kemudian rata-rata hasil belajar TIK pada kelompok siswa dengan kemandirian rendah yang diajar dengan strategi pembelajaran ARIAS lebih rendah dibandingkan dengan rata-rata hasil belajar TIK kelompok siswa dengan kemandirian rendah yang diajar dengan strategi pembelajaran Direct Instruction. Hal ini bermakna bahwa bagi 
kelompok siswa dengan kemandirian tinggi lebih baik menggunakan strategi pembelajaran ARIAS sedangkan siswa dengan kemandirian rendah lebih baik diajar dengan menggunakan strategi pembelajaran Direct Instruction. Dengan demikian dapat ditarik kesimpulan bahwa strategi pembelajaran dan kemandirian cukup signifikan mempengaruhi hasil belajar TIK siswa.

Hal ini dimungkinkan karena melalui pembelajaran ARIAS : (1) siswa lebih aktif dan memiliki motivasi untuk mengikuti kegiatan pembelajaran sehingga suasana kelas saat pembelajaran berlangsung telihat aktif dan menyenangkan, (2) siswa lebih terkesan karena dalam penerapan strategi pembelajaran ARIAS dibangun relevansi artinya berhubungan dengan kehidupan siswa dan pembelajaran lebih bermakna sehingga dapat membangun minat/perhatian siswa dalam pembelajaran, (3) siswa akan lebih merasa bangga dan dihargai dan merasa puas terhadap keberhasilan yang didapatnya sehingga akan menjadi penguat bagi siswa tersebut untuk mencapai keberhasilankeberhasilan berikutnya.

Selanjutnya hasi uji Scheffe' menunjukkan dari enam kombinasi perbandingan rata-rata hasil belajar TIK terdapat tiga dari enam menunjukkan hasil yang tidak signifikan yaitu: (1) rata-rata hasil belajar TIK kelompok siswa yang diajar dengan strategi pembelajaran Direct Instruction dan kemandirian tinggi dengan rata-rata hasil belajar kelompok siswa yang diajar dengan strategi pembelajaran ARIAS dan kemandirian rendah, (2) rata-rata hasil belajar TIK kelompok siswa yang diajar dengan strategi pembelajaran Direct Instruction dan kemandirian tinggi dengan rata-rata hasil belajar kelompok siswa yang diajar dengan strategi pembelajaran Direct Instruction dan kemandirian rendah, dan (3) rata-rata hasil belajar TIK kelompok siswa yang diajar dengan strategi pembelajaran ARIAS dan kemandirian rendah dengan rata-rata hasil belajar kelompok siswa yang diajar dengan strategi pembelajaran Direct Instruction dan kemandirian rendah tidak memberikan pengaruh yang signifikan.

Apabila dilihat rata-rata hasil belajar pada kelompok siswa dengan kemandirian tinggi dan dibelajarkan dengan strategi pembelajaran ARIAS lebih tinggi dibandingkan dengan rata-rata hasil belajar kelompok siswa dengan kemandirian tinggi dan dibelajarkan dengan strategi pembelajaran Direct Instruction. Kemudian rata-rata hasil belajar
TIK pada kelompok siswa dengan kemandirian rendah dibelajarkan dengan strategi pembelajaran ARIAS lebih rendah dibandingkan dengan rata-rata hasil belajar kelompok siswa dengan kemandirian rendah dan dibelajarkan dengan strategi pembelajaran Direct Instruction. Hal ini bermakna bahwa bagi kelompok siswa dengan kemandirian rendah lebih baik dibelajarkan dengan menggunakan strategi pembelajaran Direct Instruction daripada strategi pembelajaran ARIAS. Dengan demikian dapatlah ditarik kesimpulan bahwa strategi pembelajaran dan kemandirian belajar cukup signifikan mempengaruhi hasil belajar TIK.

Dengan memperhatikan betapa luas dan pentingnya mata pelajaran TIK maka dibutuhkan suatu strategi pembelajaran yang mampu untuk mendeskripsikan secara rinci, mendefinisikan dan memahami konsep-konsep, memahami teori-teori dan mempu mengevaluasi dan melakukan keterampilan dalam pembelajaran yang efektif dan efisien. Oleh karena itu tidaklah mutlak bahwa strategi pembelajaran ARIAS sebagai satu-satunya strategi yang diterapkan pada pembelajaran TIK. Pada materi TIK tertentu dapat diterapkan strategi pembelajaran Direct Instruction maupun startegi lainnya. Dengan berbagai ragam penerapan strategi pembelajaran pada bidang studi TIK (TIK) diharapkan siswa mampu untuk membangun atau mengkonstruksikan sendiri pengetahuan dan keterampilan yang dibutuhkan untuk memahami materi ajar bidang studi TIK. Disamping itu, penerapan strategi pembelajaran ARIAS, strategi pembelajaran Direct Instruction dan strategi pembelajaran lainnya diharapkan siswa mampu mengembangkan atau menggunakan gagasan-gagasannya dalam menyelesaikan masalah pembelajaran, sehingga pengetahuan dan keterampilan akan dapat diingat dan dipahami dalam memori jangka panjang, dan sewaktu-waktu dapat digunakan sesuai dengan kebutuhan belajar siswa.

Dari penelitian ini dapat dikatakan bahwa strategi pembelajaran disesuaikan dengan karakteristik siswa yakni kemandirian dan materi pelajaran yang akan disampaikan. Pemilihan strategi pembelajaran dan kemampuan mendesain pembelajaran TIK yang tepat dibutuhkan dan harus disesuaikan dengan karakteristik siswa sehingga akan membantu dalam menentukan strategi pembelajaran, teori belajar dan media belajar yang cocok untuk digunakan. Hal ini dilakukan agar pelajaran 
yang disampaikan dapat menarik perhatian peserta didik dan dalam setiap jam pelajaran tidak terasa membosankan.

\section{PENUTUP \\ Simpulan}

Adapun kesimpulan yang dapat ditarik dari hasil pengujian hipotesis pada penelitian ini adalah sebagai berikut :

1. Strategi pembelajaran ARIAS dan strategi pembelajaran Direct Instruction memberikan pengaruh yang berbeda terhadap hasil belajar TIK (TIK) siswa. Penggunaan strategi pembelajaran ARIAS memberikan pengaruh yang lebih tinggi terhadap hasil belajar TIK dibandingkan dengan penggunakan strategi pembelajaran Direct Instruction.

2. Tingkat kemandirian tinggi dan tingkat kemandirian rendah memberikan pengaruh yang berbeda terhadap hasil belajar TIK siswa. Hasil belajar TIK siswa yang memiliki tingkat kemandirian tinggi lebih tinggi dibandingkan dengan siswa yang memiliki tingkat kemandirian rendah.

3. Terdapat interaksi antara strategi pembelajaran dan kemandirian belajar dimana siswa dengan kemandirian tinggi lebih tepat diajar menggunakan strategi pembelajaran ARIAS, sedangkan siswa dengan kemandirian rendah lebih tepat diajar dengan strategi pembelajaran Direct Instruction.

\section{Saran}

Berdasarkan hasil penelitian yang dipaparkan pada simpulan dan implikasi hasil penelitian, maka berikut disarankan beberapa hal antara lain :

1. Berdasarkan hasil temuan penelitian bahwa strategi pembelajaran ARIAS lebih unggul dibandingkan dengan strategi pembelajaran Direct Instruction dalam pembelajaran TIK, oleh karena itu diharapkan bagi guru yang mengajar mata pelajaran TIK agar dapat menerapkan strategi pembelajaran ARIAS guna meningkatkan hasil belajar siswa. Untuk melaksanakan dan menerapkan strategi pembelajaran ARIAS guru diharapkan untuk mempelajarai langkah-langkah strategi pembelajaran ARIAS dan menyiapkan sarana pembelajaran yang mendukung pelaksanaan pembelajaran.

2. Kepada para guru hendaknya menggunakan strategi pembelajaran
ARIAS jika sebagian besar siswa di dalam suatu kelas memiliki tingkat kemandirian tinggi dan menggunakan strategi pembelajaran Direct Instruction jika sebagian besar siswa di dalam satu kelas memiliki tingkat kemandirian rendah.

3. Kepada kepala sekolah atau para guru yang berkompeten diharapkan melakukan penjajakan tingkat kemandirian siswa ketika mengelompokkan siswa dalam satu kelas untuk membantu siswa dalam memaksimalkan hasil belajarnya.

4. Kepada peneliti lain disarankan agar kiranya dapat melanjutkan penelitian ini tidak hanya pada ranah kognitif saja.

\section{DAFTAR PUSTAKA}

Arends. (1997). Classroom Instructional and Management. The McGraw-Hill Companies, Inc.

Benyamin S. (1979). Taksonomy of Educational Objectives (The Calasification of Educational Goals). Handbook I Cognitive Domain. London: Longman Group Ltd

Bohlin, M. (1987). Motivation in instructional design: Comparison of an American and a Soviet Strategi, Journal of Instructional Development vol. 10 (2), 11-14.

Beard dan Senior, (1980), Learning To Learn in Higher Education, Croom Helm Ltd, 110 St Jhon's Road, London

Callahan, G. (1966). Successful teaching in secondary schools. Chicago: Scott, Foreman and Company.

Dick, W \& Carey,L. (1996). The Systematic Design of Instruction. Fouth Edition. New York: Harper Collin College Publisher

Dimyati dan Mudjiono, (2006). Belajar dan Pembelajaran. Jakarta: Rineka Cipta

Djemari, 2008. Teknik Penyusunan Instrumen Tes dan Non Tes. Yogyakarta: Mitra Cendikia

DeCecco,J.P, (1986), The psychologi of learning and Instruction. Englewood Cliffs, NJ: Prentice-Hall

Gagne. (1983). The Condition of Learning. Japan: Holt Saunders.

Gagne dan Briggs, (1979). Principles of Instructional Design.New York: Holt, Rinehart and Winston

Gredler. (1994). Belajar dan Membelajarkan. Jakarta. PT Raja Grafindo Persada. 
Hendorn, N. (1987). Learner interests, achievement, and continuing motivation in instruction, Journal of Instructional Development, Vol. 10 (3), 11-14.

Hertbert L. Petri, (1986). Motivation: theory, research, and applications, (http://books.google.co.id, diakses 8 Agustus 2011)

Hopkins, D. dan Antes, Richard L. 1990. Classroom measurement and evaluation. Itasca, Illinois: F.E. Peacock Publisher, Inc.

Joyce . B \& Marsha Weil. (2009). Strategis of Theacing. New Jersey: Prentice Hall, Fifth Edition.

Johnson dan Medinnus .(1989). Child Psychology Behavior and Development, New York: John Wiley and Sons.

Kingsley . (1970). The nature and conditions of learning. New York. Prentice - Hall , Inc

Kiranawati. (2007). Penerapan Pembelajaran ARIAS.Artikel. Tersedia pada http://gurupkn.wordpress.com. Didownload tanggal 04 Februari 2012.

Keller, J. M. (2006). The Arcs Strategi of Motivation Design. Artikel. http://www.googlebooks.com/ArcsStrate gi. Diakses tanggal 25 Februari 2011.

Keller, J . M . (2006) . ARCS - Motivation teory .Artikel . (http/ /www. ide. ed. Psu . edu). Diakses pada tanggal 04 Februari 2012.

Keller, J. M. \& Suzuki, K (2004). Learner motivation and e-learning design: $A$ multinationally validated process. Journal of Education Media, 29 (3), 175-
189. ( http//www.arcsStrategi.com. ) Diakses pada tanggal 25 Februari 2011.

Lefrancois, Guy R. (1982). Psychology for teaching. Belmont, CA: Wadsworth Publishing Company.

Marun dkk, (1986). Studi Mengenal Kemandirian Pada Penduduk di Tiga Suku (Jawa, Batak, Bugis). Yogyakarta:FE-UGM. Laporan Penelitian

Mudhoffir. (1993). Teknologi Instruksional. Bandung: Remaja Rosdakarya

Haris. (2002). Manajemen Pelatihan Berbasis Belajar Mandiri. Yogyakarta: Pustaka Pelajar

Prayitno, (1989). Motivasi dalam belajar. Jakarta: PPPLPTK.

Reigeluth, (1987). Instruksional Theories in Action, Hilsdale, New Jersey - Hove and London : Lawrence Erlbaum, Associates, Publisher

Sanjaya,W. (2007). Strategi Pembelajaran. Jakarta: Kencana Prenada Media Group

Santrock. (2010). Psikologi Pendidikan. Jakarta. Kencana Prenada Goup.

Sukardi, (1993). Analisis Inventori Minat dan Kepribadian. Denpasar: Rineka Cipta.

Suparman,A. (2001). Desain Instruksional, Jakarta: Universitas Terbuka

Trianto. (2009). Mendesain Strategi Pembelajaran Inovatif Progresif. Jakarta: Kencana Prenada Media Group.

Wena, M. (2009). Strategi Pembelajaran Inovatif Kontemporer Suatu Tinjauan Konseptual Operasional. Jakarta: Bumi Aksara 